\title{
RELIGIOSITY AS AN INTERVENING VARIABLE IN THE CONSUMPTION PATTERN OF MOSLEM COMMUNITY
}

\author{
Habibi Ahmad \\ Faculty of Islamic Economics and Business, IAIN Raden Intan, Lampung, Indonesia \\ E-mail: ahmadhabibinoor@gmail.com
}

\begin{abstract}
Consumption is one of the basic indicators of human's life. The level of human satisfaction is always influenced by the level of economic and social change in the culture of a region. According to Kotler, religion is part of a culture that can shape people's behavior. The purpose of this study is to analyze the influence of contextual factors and religiosity on food consumption patterns in Bandar Lampung, as well as to investigate the religiosity variables as an intervening variable on the contextual factors on food consumption patterns in Bandar Lampung. The results of the analysis showed that the relative and contextual factors cannot influence the consumers' buying behavior directly but influence the religiosity (as an intervening variable) and the pattern of consumption indirectly.
\end{abstract}

\section{KEY WORDS}

Consumption, religiosity, community, food, factors.

Consumption is one of the economic activities that play a role in the economy of a country. This also one of the essential components to assess the development level of the people's economic welfare through a pattern of private consumption. According to Frank and Barnake (2001), consumption is a home-spending intended for goods and services such as clothing, food, entertainment, health, and other asset acquisitions. In the theory of Keynesian about consumption, domestic or household consumption $(\mathrm{C})$ is positively related to the family income: the more income you have, the more tendency you consume. Keynes also believes that a high-income family will consume less of their income than low-income family (Case \& Fair, 2007).

If the consumption expenditure of all people in a country is added up, this will result in the consumption expenditure of the people of the country concerned. John Maynard Keynes (June $\left.5^{\text {th }}, 1883-A p r i l 21^{\text {st }}, 1946\right)$ in Raharja \& Manurung (2008) wrote the Keynes theory of consumption, "consumption done today depends on the disposable income today. In short, consumption $(\mathrm{C})$ is affected by disposable income $(\mathrm{Yd})$ ". If the income is increasing, the consumption will increase as well. Nevertheless, Keynes stated that the consumption curve will later be curved which means that the income received will not be big even though the consumption becomes longer.

Consumption is one of the basic indicators of human's life. The level of human satisfaction is always influenced by the level of economic and socio-cultural changes in an area (Dimitrov \& Atanasova, 1963). Kotler (2000) said that religion is part of a culture that can shape people's behavior. In particular, people who have a religion hold certain values that can influence their actions and decisions. Islam is a religion that guides Moslems in every aspect of life, not just in specific acts of worship. For example, in one of the chapters of The Koran, Chapter Al-Isra': 26-27, Allah, God Almighty, instructs Moslems not to consume or spend money on luxury things but to spend in the way of Allah. Moreover, Islam has also given guidelines on how and what can be traded, on how to interact with others, and on what can be consumed. The consumption of food and drink in Moslems' daily lives is strictly arranged in Islam.However, the implementation in the society occurs differently due to its level of understanding which is varied.

The purpose of this study is to analyze the influence of contextual factors and religiosity on food consumption patterns in Bandar Lampung, as well as to investigate the religiosity 
variables as an intervening variable on the contextual factors on food consumption patterns in Bandar Lampung.

\section{LITERATURE REVIEW}

The term "consumption" is taken from the Latin "consumere" which means spend, and of the English language means taking and spend (Sudarsono, 1984: 8). Consumption expenditure consists of government expenditure and household consumption. The focus in this study is the household consumption due to the fact that, up to now, household consumption has the largest share of total aggregate expenditure. Given the large share of household consumption, this has a major impact on the economic stability (Rahardja \& Manurung, 2001). Keynes put forward a general theory of revenue, money, interest, and employment in which the center of the theory is about consumer behavior in allocating its income for consumption and savings.

Various studies conducted by Alam and Hisam (2011) explained that the decisionmaking of a consumer is influenced by religiosity as a mediating factor in the purchase. Based on the research of Razzaque \& Chaudhry (2012), educational variables and religious understanding are the determinants of the decision. In another study, Bahri (2014), Ernita et al (2013), Shandra (2012), and Susilowati (2010) concluded that the consumption patterns of Moslem consumers only seem to meet the basic and secondary needs without considering the concept of Islamic guidance in the decision-making. The theory of consumer behavior developed by the Western after the rise of capitalism is the descendant of duality, namely "economic rationalism" and "utilitarianism". Economic rationalism interprets human behavior as a "rigorous" calculation that is directed with foresight and caution towards economic success. Moreover, economic rationality assumes that consumers will aim to maximize their "satisfaction" in a unique sense which is not entirely a devoid of utilitarian significance. It is said that the concept does not apply to a certain kind of satisfaction, whether spiritual, material or otherwise (Adila, 1999).

Rationalism in Islam is defined as a reaching point through moderation in consumption. According to Siddiqi (1992), a rational Moslem individual will try to behave (in its utmost effort) in accordance with consumer norms. There are four goals of consumption to be achieved in Islam, namely:

1. Everyone should consume enough economic goods to have an efficient life.

2. Particular goods are prohibited to be consumed.

3. The consumption of economic goods does not have to be wasteful as excessive, Exposing such luxury life is not recommended.

4. The consumption of economic goods and consumer satisfaction should not be the ultimate goal of the individual. It should serve as a means for achieving the higher goals of the purpose of life.

Hamouri (1991) modified the conventional model based on Moslem consumers. It is found that they consider the effects of Islamic teachings on their behavior. Hamouri revealed that Moslems will choose to consume the most preferred items but should be allowed in Islam. In this case, unreachable items (unlawful or haram items) will not be selected. Zaman in his research added three new axioms:

1. Lexicographic preferences (some preferences that are more urgent than others);

2. The utility of basic needs which can be met; and

3. Externality in secondary utilities (the utility derived from the function of other consumption bundles).

In general, religion will influence the behavior in society especially on the material and attitudes toward possession and utilization of goods and services. Religious traditions may prohibit the use of certain goods and services, for example, Islam forbids its followers from drinking alcohol and eating pork while Hindus worship the cow by making them not to eat beef. Religion also affects people's actions due to the rules in the worship, as for an example, by prohibiting the use of certain contraception methods. In such cases, religious 
values could form an emotional experience as well as cognitive and psychological awareness which in turn will influence the decision-making of the consumer's consumption.

There are several studies on the relationship between religiosity and consumer behavior with the general conclusion that there is a real relationship. Adila (1999) conducted a survey among Moslem and non-Moslem communities living in Singapore to investigate whether or not they understand Islam as a reference in the purchases. The findings showed that Moslems in Singapore are generally a moderate consumer showing that moderation, as one of the main concepts of the Islamic consumption model, is being practiced. The research was conducted in a place where $85 \%$ of Singapore's population are non-Moslems. Therefore, the respondents did not describe the demographics of the country. This study only concentrates on the consumed goods to meet the physiological needs, such as food and clothing, or on non-durable items. Thus, we can not see the behavior of Moslem consumers in purchasing durable goods, especially when buying a car (today, this is considered as a necessity).

A study by Zaidman and Lowengart (2001) investigated the interactions between consumers and retailers in the marketing of religious goods and services at the time of pilgrimage to the tomb of Jewish saint in Israel. The research was attempted to analyze the process of personal items exchange such as sacred objects (eg Jewish text books, candles, amulets, and crystals) and services (eg blessing, healing) that are transferred directly from sellers to consumers. By using ethnographic approach, they found that the process of obtaining sacred goods is not only involving the goods themselves but also the influence of the seller. The process of marketing meditation to infuse originality or authenticity into their products or services is monotonous in which this is associated with the proximity of the retailer to the culture of the consumer.

Fam et al., (2004) carried out a large-scale research analyzing the effects of religion and intensity of religious beliefs on consumer behavior toward the advertisement of four controversial products. This includes the products used by consumers with different genders such as clothing for women and men, products related to social and political significance such as armors and funeral services, products related to health and personal care such as weight loss programs, and addictive products such as cigarettes and alcohol by using students as samples from four major religious groups such as Buddhists, Moslems, Christians, and non-believers (especially Taoism and Confucianism) in six different countries.

In the research, they found that the followers of those four religions have different attitudes toward the four controversial products. It is showed that Moslems are more likely to be offensive against the advertising of the four products compared to the other three religions. The study also revealed that the devout or religious followers are more likely to consider the advertising based on the sexes such as for clothing for men and women, health, and personal care products, as well as addictive products compared to consumers who are not devout. Gayatri et al., (2005) found that a Moslem who holds Islamic cultural values may influence the criteria of service quality evaluation in restaurants, hotels, and airlines. Religiosity can influence attitudes and lifestyle, information search, purchase risk-taking, attitudes toward advertising, and durable goods purchasing behavior. Thus, there is a sufficient evidence to support the application of religiosity in explaining consumer behavior.

Bahresy (1981) described the fundamental principle of consumption in Islam saying that everything from Allah is halal and nothing haram unless if there is a prohibition stated in Nash (proposition) that is authentic and sharih (clear). Actually, in the Qur'an, there is only four haram food as written in The Koran, Chapter Al Baqara, verse 173:

Translated as: Allah only forbids you carcasses, blood, pigs, and animals that (when slaughtered) is called (name) other than God (Allah) [108]. But whoever is forced to eat (is not wanting it) and does not transgress, there is no sin for him. Allah is Forgiving, Allah is Merciful.

So, it can be concluded that the terms of halal food according to Islam is that the material contained is halal, including halal in acquiring it, halal in the processing, halal in the storage, and halal in the transport and presentation. 
Thus, based on the aforementioned discussion, this study formulated three hypotheses as follows:

- $\mathrm{H}_{1}$ : contextual factors influence the pattern of food consumption in Bandar Lampung society;

- $\mathrm{H}_{2}$ : religiosity can influence the pattern of food consumption in Bandar Lampung society;

- $\mathrm{H}_{3}$ : religiosity can mediate the contextual factors that influence the pattern of food consumption in Bandar Lampung society.

\section{METHODS OF RESEARCH}

A cross-sectional research design was used to test the relationship between independent factors, the level of halal product understanding among Moslems in Singapore which have complete educational facilities from kindergarten, elementary school, middle school, high school, and college based on Islam as well as have several non-formal Islamic educational institutions, which of course, will affect their purchasing decisions. The influence of religion is only tested on food purchases.

The instruments contain sub-sections. The subdivision of the instrument is taken from different previous studies. Adila (1999) used the practice of Islam (charity) as a clearer measure of diversity that is visible from other dimensions in Islam, namely; Knowledge (ma'rifat), faith (iman), consequences and realization (ihsan). Islamic practice includes a set of behaviors that are expected in a Moslem.

The adoption of the items is derived from Alam and Hisham (2011). In addition, it was determined by the respondent's perception towards the importance of religious practices in daily lives. The researchers assume that respondent's opinion reflects real behavior such as putting the perception of their behavior on a particular item. To check the validity of the proxies, respondents were asked to rate themselves in terms of their knowledge of halal products. The responses to all items were made on a 5-point scale (1 - strongly agree, 2 agree, 3 - neutral, 4 - disagree, and 5 - strongly disagree). One question contains five possible responses about how respondents see halal products. This study relies on the ratings which are based on the responses received from the proxy statement as follows:

The sub-section of the questionnaire on relative and contextual factors is developed by researchers where the items are measured on a 5-point Likert scale ranging from 1 - strongly disagree to 5 - strongly agree.

The sub-section of the questionnaire on pre-decision and post-decision making where the items are measured by using a 5-point Likert scale ranging from 1 - strongly disagree to 5 - strongly agree.

This instrument, basically, consists of four sections in which the questions are distributed in accordance with the demographic variables, relative and contextual variables, as well as before and after the decision-making of Moslem consumer in the purchase.

Furthermore, to ensure the data validity and reliability, a pre-test with the questionnaire was conducted by selecting some consumers and professionals. After the final survey was given, the response analysis showed no problems with the survey design. Various constructions were tested for data validity by using a principal analysis of components with rotation. As a result, all items were maintained because there was no crossed load and were published as a single factor. In regarding with data reliability, the surveys had strong internal consistency with all multiple-item constructions that exceeded the acceptable standards of reliability analysis by 0,70 (Nunnally and Bernstein, 1994). Hence, the items were considered acceptable. The results showed that all the constructions were valid and reliable.

Meanwhile, the subjects of this study were consumers who have savings in Islamic banks in Bandar Lampung City, Indonesia. Furthermore, the data used were primary data which are the data obtained from respondents through a questionnaire.

In this study, the population was the people living in Bandar Lampung City. The total population was not limited; therefore, the determination of the samples was taken by using the table determination of a specific sample developed from Isaac and Michael with an error 
rate of $1 \%$ (Sugiyono, 2008). Based on the table determination, the population in this study is infinite so that the number of samples obtained are 664 samples.

The data was taken directly by distributing questionnaires to the respondents (Islamic bank customers).

In this study, the data collection was carried out by using questionnaire. The questionnaire was a data collection technique that is done by giving a set of questions or written statement to be answered by the respondents. This questionnaire method is used to obtain research data. To measure the scale of the assessment that is in the questionnaire, a Likert scale was used.

\section{RESULTS AND DISCUSSION}

Characteristics of Respondents. The results showed that the majority of respondents are male as many as 380 people while as many as 279 people are aged $25-35$ years. Most respondents have private employees and earn 1 to 3 million rupiahs per month as many as 359 people.

Table 1 - Characteristics of Respondents

\begin{tabular}{|c|c|c|c|}
\hline \multicolumn{4}{|c|}{ Respondents } \\
\hline Sex & & Age & \\
\hline Male & 380 & Less than 25 years & 139 \\
\hline Female & 284 & $25-35$ years & 279 \\
\hline & & More than 35 years & 246 \\
\hline Job & & & \\
\hline Student & 146 & Income & \\
\hline Civil servant & 129 & Less than 1 million rupiahs & 93 \\
\hline Private employee & 286 & 1 million -3 million rupiahs & 359 \\
\hline Merchant & 53 & More than 3 million rupiahs & 212 \\
\hline Others & 50 & & \\
\hline
\end{tabular}

Test Results. The first hypothesis shows that relative and contextual factors had no effect on food consumption pattern in Bandar Lampung society indicated by the coefficient of 0.050 and a significant level of more than 0.05 .

Table 2 - Research Results

\begin{tabular}{|l|c|c|}
\hline \multicolumn{1}{|c|}{$\mathrm{n} / \mathrm{n}$} & Religiosity & Consumption Pattern \\
\hline Relative and contextual factors & $0.656^{*}$ & 0.050 \\
\hline Mediation variable of religiosity & - & $0.552^{*}$ \\
\hline R2 & 0.434 & 0.310 \\
\hline Adjust R2 & 0.424 & 0.295 \\
\hline F & 73.870 & 21.758 \\
\hline
\end{tabular}

Significant to ${ }^{*} p<0.01$.

The second hypothesis indicates that religiosity could influence food consumption pattern in Bandar Lampung showed by the coefficient of 0.552 and a significant level of less than 0.05 .

Furthermore, the third hypothesis with religiosity as a mediating variable is tested. The SPSS output above provides a standardized value of beta Earns in the equation (1) 0.656 and significant at the 0.000 . This means that the relative and contextual factors influence religiosity. The coefficient value of standardized beta by 0.656 is a path value or p2 paths. At the SPSS output, the regression equation is (2) the value of the standardized beta of relative and contextual factors by 0.050 and religiosity by 0.552 and only that religiosity is significant. The value of standardized beta of relative and contextual factors by 0.050 is the value of $p 1$ path and the value of standardized beta of religiosity by 0.552 is the value of p3 path. 


\section{DISCUSSION OF RESULTS}

The results of the analysis showed that the relative and contextual factors can not influence the consumers' buying behavior directly but influence the religiosity (as an intervening variable) and the pattern of consumption indirectly. The amount of direct influence is 0.050 while the amount of the indirect effect should be calculated by multiplying the indirect coefficient that is $(0.656) \times(0.552)=0.362$. Therefore, the coefficient of direct relationship is smaller than the coefficient of indirect relationship. So, it can be said that the true relationship within is indirect. This shows that $\mathrm{H} 3$ is accepted, meaning that religiosity is able to mediate the influence of relative and contextual factors towards consumption patterns.

All the examined hypotheses in this study support the assumption that religion has a greater influence on Moslems' purchasing decisions. Therefore, it is true that, in Islam, the consumption patterns are governed by the religious orders. This challenges the assumption on the consumption pattern in the conventional economy. One of the purposes of this study was to test whether the results of the hypothesis can be empirically supported or not.

In accordance with the research of Alam (2011), Moslem people take Islam as a source of reference when making purchases in general and in specific. This is consistent with the verses that Islam commands Moslems to adhere the guidance of Allah and spend revenue to an enough or humble consumption. The study also shows that those who are religious tend to be less impulsive when making decisions in the pattern of consumption. Meanwhile, the effects of religiosity in expenditure have not been studied previously. These findings seem to be consistent with the literature indicating that individuals who are highly religious tend to have a mature, disciplined, and responsible consumption behavior.

\section{REFERENCES}

1. Achenreiner, G.B. (1997), "Materialistic values and susceptibility to influence in children", Advances in Consumer Research, Vol. 24

2. Adila, A.B. (1999), "Islamic attributed in consumer decision making: an empirical study in Singapore", Non publication thesis of Master's, IIUM, Kuala Lumpur

3. Alam, H. (2011) "Is Religiosity an important determinant on Moslem consumer behavior in Malaysia". Journal of Islamic Marketing Vol 2 no 1.

4. Bahresy, H. (1981), "Pedoman Fiqh Islam", Surabaya: Al-Ikhlas.

5. Bahri, A. (2014). "Etika Konsumsi dalam Perspektif Ekonomi Islam". Himafa (Jurnal Studi Islamika), Vol II.

6. Case, K.E. \& Fair, R.C. (2007). "Prinsip-prinsip ekonomi”. Jakarta: Penerbit Airlangga.

7. Dimitrov, A. (1963). Food Consumption Inn Bulgaria. Ikonomicheska Misul No 3.

8. Fam, K.S., Waller, D.S. and Erdogan, B.Z. (2004), "The influence of religion on attitudes towards the advertising of controversial products", European Journal of Marketing, Vol. 38 Nos 5/6.

9. Gayatri, G. (2005), "Understanding service quality from the Islamic customer perspective". In Purchase, S. (Ed.), Proceedings of the Australian and New Zealand Marketing Academy Conference, University of Western Australia, Perth.

10. Kotler, P. (2000), "Consumer market and consumer behavior", Principles of Marketing, 8th ed., Prentice-Hall, Upper Saddle River, NJ

11. Rahardja, P. \& Manurung, M. (2004). "Pengantar Ilmu Ekonomi (Mikroekonomi dan Makroekonomi)". Jakarta: Penerbitan Fakultas Ekonomi Universitas Indonesia.

12. Siddiqi, M.N. (1992), "Islamic consumer behavior", in Tahir, S., Ghazali, A. and Agil, S.O. (Eds), Readings in Microeconomics: An Islamic Perspective. Selected Readings, Longman, Kuala Lumpur, pp. 49-60.

13. Sudarsono. (1984). "Pengantar Ekonomi Mikro". Yogyakarta: LP3ES.

14. Sugiyono. (2009). "Metode Penelitian Bisnis". Bandung: Alfabeta.

15. Zaidman, N. (2001), "The marketing of sacred goods: interaction of consumers and retailers", Journal of International Consumer Marketing, Vol. 13 No. 4, pp. 5-27. 